\begin{tabular}{|c|c|}
\hline [णㅍำ] & $\begin{array}{l}\text { Jurnal Penelitian dan Evaluasi Pendidikan } \\
\text { Volume 23, No 2, December } 2019 \text { (156-169) }\end{array}$ \\
\hline litian dan Evaluasi Pendidikan & Online: http://journal.uny.ac.id/index.php/jpep \\
\hline
\end{tabular}

\title{
AN EVALUATION OF MATHEMATICS LEARNING PROGRAM AT PRIMARY EDUCATION USING COUNTENANCE STAKE EVALUATION MODEL
}

\author{
Bayuk Nusantara Karaeng Jannang Tompong \\ Universitas Negeri Yogyakarta \\ Jailani \\ Universitas Negeri Yogyakarta
}

\begin{abstract}
The quality of mathematics learning in Bantaeng Regency, South Sulawesi were in a low category based on the research findings from the Institute of Educational Quality Assurance of South Sulawesi in 2011. It affects students to be unwilling to be involved in the process of mathematics learning. This study aims to evaluate the process of learning mathematics in the elementary educational level at Bantaeng Regency. The model of evaluation used in this study is the Stake Countenance Model consisting of three steps of evaluation, namely antecedent, transaction, and outcomes. The subjects of this study were 12 teachers at state elementary schools in Bantaeng Regency assessed by three raters. There were 363 midterm score tests from 12 schools. The instruments used in this study were observation sheet, lesson plan sheet, assessment documentation sheet, and interview guideline. This study used a quantitative research approach supported by qualitative data. The result of the study shows that (1) the lesson plan of mathematics subject is in a good category $(93.45 \%)$, (2) the learning process is in the good enough category $(67.07 \%)$, (3) the document of students assessment is in the good enough category $(71.34 \%)$, and (4) most students in each school do not pass the school standard.
\end{abstract}

Keywords: evaluation, mathematics learning, Countenance Stake model

Permalink/DOI: http://dx.doi.org/10.21831/pep.v23i2.16473

Contact: Bayuk Nusantara Karaeng Jannang Tompong

bayuknusantara@gmail.com

Department of Educational Research and Evaluation, Graduate School,

Universitas Negeri Yogyakarta

Jl. Colombo No. 1, Karangmalang, Depok, Sleman, Yogyakarta 55281, Indonesia 


\section{Introduction}

Education is the success key to any aspect because you can improve yourself through education. In Indonesia, there are two kinds of education namely formal and informal education. Formal education is divided into three steps which is primary, secondary, and higher education. Education at the elementary level is a program that involves some components in order to achieve the aim of the program. As a program, education is conscious and deliberate activity directed to achieve the goal (Salmayzuri, Ruslan, \& Pristiwaluyo, 2015). Thus, it can be concluded that the education program in primary education is a program that has some components to achieve an educational goal.

In elementary education, some subjects have been taught, one of which is mathematics. Mathematics is taught both in primary and secondary education. Students know how important mathematics is, but some of them find it difficult so that their awareness in learning math is still not enough (Rosnani, Sugiyono, \& Tampubolon, 2015). They think that math is difficult to learn then they are burdened to learn math (Mardapi, 2009). The difficulty is not only about the subject but also the teacher.

Teachers play an important role in learning mathematics. How students view mathematics is influenced by the teacher. Bahri and Alimuddin (2016) state that teachers should know students' needs so that they can plan the learning as fun as possible then students will enjoy the learning process. Teachers can find a solution if there is a problem in learning.

Mathematics learning is a process in building a structured mathematics concept for students so that they get mathematic knowledge through experience in the teaching and learning process. There are three steps of mathematics learning, namely preparation, implementation, and assessment. These steps should run well so that students get maximum learning experience. Mathematics learning is regulated by the government.
The learning process is designed by applicable standards. These standards ease teachers in planning, implementing, and assessing. Burton and Kappenberg (2013, p. 9) state that standard is divided into three, elaborated as follows. (1) It should provide information about learning content that should be mastered by students specifically. (2) It helps teachers in determining knowledge based on students' needs. (3) It should help the country and province in assessing program effectiveness and learning method.

Furthermore, standards for the learning process consist of content, process, assessment, and graduate competence standards. The content standard is a fundamental thing in developing a curriculum or lesson plan. Burton and Kappenberg (2013, p. 14) insist that "the content standards set priorities for broad topics by grade level". In other word, content standard is the basis for curriculum development based on educational level. The content standard is used as the basis of the arrangement, implementation, and also assessment in the learning process. Content standard in Kurikulum Tingkat Satuan Pendidikan (KTSP) or schoolbased curriculum is arranged in the Regulation of Minister of National Education No. 22 of 2006 which contains the minimum scope of the material and minimum level of competence to achieve minimum competencies for graduates at certain levels and types of education. The implementation of learning process is regulated in process standard.

Process standard is a national standard of education related to the learning process in an education unit to achieve graduate competence standard (Regulation of the Minister of National Education No. 19 of 2005, chapter 1 article 1 verse 6). Process standards are a reference for education implementers in conducting or implementing learning in the classroom. Thus, the teacher has guidelines for implementing learning. The standard process includes three activities related to each other, namely, planning the learning process, implementing the learning process, and evalu- 
ating the learning outcomes. The process standard refers to the Regulation the Minister of National Education of Republic of Indonesia No. 41 of 2007 which contains the minimum criteria for the learning process in primary and secondary education units in the entire jurisdiction of the Republic of Indonesia. This standard is also related to the implementation of learning in education units to achieve graduate competence. This standard applies to primary and secondary education at the formal track, both in the package system and in the semester credit system. Process standards can be used as a reference for teachers in developing the learning process, but process standards are not an obligation. Process standards are a reference, but the teacher must develop the process in accordance with the conditions of each student so that students' learning outcomes are better.

'Teachers' activities in conducting assessments are regulated in the assessment standards. Assessment standards contain knowledge about the philosophy and purpose of the assessment (van de Walle, 2008, p. 6). Thus, Walle reports that in the assessment standards, the form of assessment along with its purpose is mentioned. In contrast to these standards, assessment standards, according to the National Education Standard Agency or Badan Standar Nasional Pendidikan (BSNP), include mechanisms, procedures, and instruments for assessing student learning outcomes. The assessment standards referred to by teachers are based on the Regulation of the Minister of National Education No. 20 of 2007 which contains the standards for conducting assessments. With the existence of assessment standards, teachers are expected to be able to develop forms of assessment following students' needs.

Therefore, teachers in Indonesia have a reference in implementing the learning process, namely: content standards, process standards, and assessment standards. The three standards are set by the National Education Standards Agency (BSNP). Content standards are used as a basis for the preparation of learning designs, learning processes, and assessment processes. The implementation of learning is regulated in a standard process. Process standards are implemented to achieve graduate competency standards. Teachers' guidelines for conducting assessments are contained in the assessment standards. Assessment standards include mechanisms, procedures, and instruments for assessing student learning outcomes.

Learning mathematics in elementary school consists of three stages (Singh, 2008, p. 28). The first stage is the preparation phase. The preparation phase is everything that is done by the teacher before learning begins. Teaching preparation includes the making and preparation of a learning plan, the material to be used, the learning method chosen, the learning objectives themselves, and determining what activities are carried out to meet the learning objectives. A teacher is required to make a learning plan that is intended to facilitate the teacher in implementing the learning process. The making of lesson plans by teachers should be based on content standards that have been determined by the government. This statement is supported by Maryani and Fatmawati (2015, p. 75) who explain that the lesson plan is designed based on content standards. The importance of the learning plan was expressed by Niwaz, Shah, and Rajper (2016) who reveal that learning planning which is carried out regularly can improve the effectiveness of mathematics learning, because the learning plan is a document that has the idealism of the teacher in implementing the learning process so that when the lesson plan is implemented properly by the teacher, then, it can improve the effectiveness of mathematics learning.

The second stage is the process of learning implementation. The learning process will be more meaningful when the teacher implements a lesson plan that has been made. The learning process has three stages, namely the preliminary, main, and closing stages. Andriani (2015) says that 
there are three activities in the implementation of the mathematics learning process, namely preliminary, core, and closing activities. The results of research conducted by Andriani show that the teacher had carried out the learning process but some activities were considered to be not optimal. Every stage in the learning process should refer to the standard process. The appropriateness between the learning plans that are made and what happens on the field deserves attention.

The last step in implementing mathematics learning is assessment. Assessment is defined as an activity that can be done either before learning, when learning, or when learning ends to get information both quantitatively and qualitatively with specific objectives (Kasih \& Purnomo, 2016). Thus, assessment is done to know students' understanding of the material so that it can be done anytime. In the learning process, teachers are required to conduct an assessment to find out how far students can absorb what has been taught in the learning process. The complete assessment documents are contained in the assessment standards making it easier for teachers to complete the assessment documents. Assessments made by teachers can be in the form of daily assessments, midterm tests, and end of semester tests.

A program is said to have achieved its goals if it obtains information about the usefulness of a program. In line with this idea, Fitzpatrick, Sanders, and Worthen (2011) say that evaluation is an activity to determine the usefulness of an evaluation object. In other words, evaluation is an activity to identify, clarify, and apply several criteria to determine whether a program is useful or not. Evaluation leads to a decision. Thus, the result of the evaluation is a decision whether the program is useful or not so that policymakers can decide the sustainability of the program.

Evaluation is a systematic activity. Consequently, evaluation has a procedure of activities in its implementation. Rossi and Freeman (1985, p. 19) explain that evalu- ation is an activity that has certain procedures in assessing the application of a program. Therefore, the evaluation uses certain procedures to provide an assessment to increase the planning, monitoring, effectiveness, and efficiency of a program.

\section{Evaluation Model of Countenance Stake}

The Stake's Countenance Model is an evaluation model which was developed by Robert Stake in 1967. Stake (1996) argues that evaluation can provide an overall picture of the implementation of a program so that it can be given consideration afterward. It means that an evaluation model must be able to provide comprehensive information about what is being evaluated, both the measurement results and judgment.

Stakes' Countenance Model consists of two activities: description and assessment. Each activity consists of three aspects that are of concern to an evaluator in evaluating a program, namely, Antecedents (Context), Transactions (Process), and also Outcomes (Output) (Kaufman \& Thomas, 1980).

The Countenance Stake evaluation model is widely used in research evaluating the learning process. Lukum (2015) evaluates the junior high school natural science learning program in Bone Bolango Regency using this evaluation model. Observation, interview, and documentation techniques were used in gathering information. The results of this study mention that learning planning is still not in accordance with the standards. The second finding is about the learning process that is still not in accordance with the standard process. It results in students' grades that still do not meet the specified minimum completion criteria or Kriteria Ketuntasan Minimal (KKM) grades. This study is in line with research conducted by Dole and Wibowo (2013) which says that teachers' understanding of School-Based Curriculum (SBC) is very low so that it results in the implementation of $\mathrm{SBC}$ in the classroom. Dole and Wibowo (2013) have found that the ability of teach- 
ers in the implementation of SBC (planning, implementation, and assessment) was still in the low category. This research was conducted at several elementary schools in Ende.

In contrast to research conducted by Lukum, Waluyati (2012) has found that learning planning in junior high school or Islamic-based junior high school in the City of Bima is categorized as good or in accordance with the standards. Furthermore, student learning outcomes already meet the KKM or good grades. This is different from the previous study which said that the learning process was not appropriate, so that resulted in student learning outcomes at the time of the study conducted by Waluyati, the learning process was included in the quite good category with good learning outcomes.

Wibowo and Wutsqa (2014) obtain the same results, namely, a compilation of good planning, then, will produce a good learning process and student learning outcomes. This research is evaluation research on the implementation of Kurikulum Tingkat Satuan Pendidikan (KTSP) or School-Based Curriculum for mathematics in junior high school in Yogyakarta City. The results show that the planning made by the teacher is in a good category, the learning process is in a good category, and the learning outcomes are in a good category. This third thing happens because teachers' understanding of $\mathrm{SBC}$ is also in the good category. Thus, the teacher has sufficient knowledge in conducting learning.

One of the causes of students' difficulty in learning mathematics is the challenge. Ramirez, Chang, Maloney, Levine, and Beilock (2016) state that teachers must become compatible with mathematics. In other words, the teacher must be able to solve every mathematical problem that is done by students so the teacher must have some references to it.

A research conducted by Setiawan (2016) is classroom action research. The research aims to improve student learning outcomes with the paper props method. The results show that the ability of teachers and students improve after using paper props. The teacher improves the way of teaching given to the results of reflection so that students' abilities increase. Thus, it can be concluded that student learning outcomes can be improved by improvements made by the teacher during the learning process. In other words, the learning process must run according to the applicable minimum standards.

It was stated in the report of the results of school self-evaluation conducted by the Institute of Educational Quality Assurance or Lembaga Penjaminan Mutu Pendidikan (LPMP) of South Sulawesi Province in 2011, that the achievement of national education standards in Bantaeng Regency is still in the low category. Some of them are still at minimum service standards. In the data, it is stated that the highest achievement is only in the implementation of the assessment. It can be interpreted that the quality of education delivery in Bantaeng Regency is still lacking. This assessment is carried out by each school as a need to improve school performance and quality. However, this evaluation is an internal evaluation that might be biased because it was done by the school principal. Therefore, it is necessary to hold an evaluation of the learning process in schools conducted by evaluators who are not from the school environment.

Based on the background and some theoretical studies regarding evaluation and learning, the research objectives are (1) identifying the suitability of learning planning; (2) identifying the suitability of the learning process; (3) identifying appropriateness of learning assessment; and (4) identifying student learning outcomes.

\section{Research Method}

This research was descriptive evaluation research with a quantitative approach supported by qualitative data, where the object to be evaluated was the implementation of elementary school mathematics 
learning. There were several stages in the implementation of mathematics learning, starting from the planning, implementation, to evaluation stages in Bantaeng Regency, South Sulawesi.

The evaluation model used is the Countenance Evaluation Model. The model is an evaluation model developed by Stake which emphasizes the implementation of two main components, namely: (1) description (description) and (2) considerations (judgments), and dividing the evaluation object into three things, namely: (a) antecedents (context evaluation); (b) transactions (evaluation of the process); and (c) outcomes (evaluation of outputs and outcomes) (Fernandes, 1984). The selection of this evaluation model is based on the formulation of the research problem, which is to find out the implementation of mathematics learning for elementary school students as a whole (planning, implementing, and evaluating learning) where the three evaluation objects are in the Countenance Evaluation Model.

This research was conducted in 12 public elementary schools in Bantaeng District, Bantaeng Regency, South Sulawesi. The selected school is a public school that uses a school-based curriculum or KTSP. At the research site, only classes V and VI still use KTSP. The selection of class V is based on the ongoing learning process. The determination of the sample from this study used a purposive sampling technique in which the research sample was taken on the basis that the class V's teachers were not fixated with the National-Based School Final Examination so that observations of the learning process could be made.

In this study, the data to be collected was a description of planning, implementing, and also evaluating elementary school mathematics learning. Data collection in this study was conducted using non-test techniques using observation, documentation, and interview techniques. First, an observation aims to see the implementation of learning undertaken by the teacher. Second, documentation aims to obtain information about the Learning Program Plan or Rencana Pelaksanaan Pembelajaran (RPP) prepared by the teacher, assessment documents, and student mathematics learning outcomes. Finally, interviews with teachers are used to obtain secondary information regarding the implementation of elementary school mathematics learning.

Validity is an index that shows how far the accuracy of the instrument is in carrying out its functions (Azwar, 2016, p. 8). A research instrument is said to be valid if it is able to measure what should be measured. Therefore, research instruments need to be estimated for validity before going into the field. The validity that was used in this research is content validity. Content validity is validity where evidence of validity is obtained from estimates made by competent experts in the measured field (Mardapi, 2012, p. 39). Validity estimation of the observation sheet was done with the help of experts (expert judgment) who later provide an assessment of each instrument item.

The results of the estimation of content validity by using the Aiken index formula for 21 items in the lesson plan review sheet instrument indicate that four items (items 12, 17, 19, and 20) have a high coefficient of validity, while the other 17 items have a medium coefficient of validity. The results of the estimation of the content validity of 34 items in the observation sheet instrument using the Aiken index formula indicate that there are five items (items 1, 2, 15,32 , and 33) that have a high coefficient of validity. Meanwhile, 29 of the 34 observation sheet instrument items are in the medium category. The results of the estimation of the content validity of 15 items in the assessment sheet instrument of the assessment document using the Aiken index formula show that there are six items (items $8,10,11,12,13$, and 14) having a high coefficient of validity. Nine of the 15 items of the instrument review sheet of assessment documents fall into the medium category. 
Reliability is an index that shows the extent to which a measuring instrument can be trusted or reliable. It means that the instrument can be said to be reliable if the instrument is used to measure something with the same symptoms twice or more and the results are relatively consistent. The reliability of an instrument is determined by the reliability coefficient. Observation sheet is used to observe the process of implementing mathematics learning in class. The lesson plan review sheet was used to determine the suitability of the lesson plan with the syllabus, while the assessment document review sheet is used to determine the suitability of the assessment document with the assessment standard. To estimate the reliability of the observation sheet, the lesson plan review sheet, and the evaluation document review sheet, interrater reliability was used. The reliability of the three instruments used the Fleiss' Kappa scale which states the coefficient $>0.40$ is reliable (Gwet, 2012, p. 125). Reliability for each instrument is $0.931,0.966$, and 0.977 .

The main data in this study was quantitative data supported by qualitative data. Data analysis techniques in this study used quantitative descriptive. Information obtained from observations and documentation was analyzed using quantitative analysis. The quantitative data were analyzed with three stages of data scoring, data tabulation, and data applications. In this study, data analysis was determined based on the ideal mean and ideal standard deviation. Achievement of respondents' scores on each instrument was processed and compared with the category formula by using the ideal mean and ideal standard deviation and then was used as interpretation material. The categorization for processing quantitative data referred to the categorization proposed by (Azwar, 2017, p. 148), as presented in Table 1.

The antecedent aspects of this study were measured through the components of the learning plan (RPP). To get the results of an assessment of the learning planning, the analysis technique of the learning planning documents was used. In this component, there were 21 grading statements that must be filled by three raters with a range of scores from 1 to 4 . Then it could be seen, the highest ideal score is 84 and the lowest ideal score is 21 . Thus, the ideal average (M) $=1 / 2(84+21)=52.5$ and for ideal standard deviation $(\mathrm{SD})=1 / 6(84-21)=10.5$. Evaluation criteria according to the ideal formula are presented in Table 2.

In the aspect of the transaction (program implementation), assessment is carried out on the implementation of learning and also the study of assessment documents that have been made by the teacher. The learning process is measured through observation of the learning activities in class. In these components, there are 34 items with a range of scores from 1 to 5 . Then it can be seen, the highest ideal score is 170 and the

Table 1. Categorization of Quantitative Data Processing

\begin{tabular}{cc}
\hline X score & Category \\
\hline $\mathrm{X}>\mathrm{M}+1.5 \mathrm{SD}$ & Very good/ very effective \\
$\mathrm{M}+0.5 \mathrm{SD}<\mathrm{X} \leq \mathrm{M}+1.5 \mathrm{SD}$ & Good / effective \\
$\mathrm{M}-0.5 \mathrm{SD}<\mathrm{X} \leq \mathrm{M}+0.5 \mathrm{SD}$ & Pretty good / effective enough \\
$\mathrm{M}-1.5 \mathrm{SD}<\mathrm{X} \leq \mathrm{M}-0.5 \mathrm{SD}$ & Poor / less effective \\
$\mathrm{X} \leq \mathrm{M}-1.5 \mathrm{SD}$ & Not good / ineffective \\
\hline
\end{tabular}

Table 2. Evaluation Criteria of Lesson Plan

\begin{tabular}{cc}
\hline Interval & Criteria \\
\hline $\mathrm{X}>68.25$ & Very good \\
$57.75<\mathrm{X} \leq 68.25$ & Good \\
$47.25<\mathrm{X} \leq 57.75$ & Pretty good \\
$36.75<\mathrm{X} \leq 47.25$ & Poor \\
$\mathrm{X} \leq 36.75$ & Not good \\
\hline
\end{tabular}


lowest ideal score is 34. Thus, the ideal average $(M)=1 / 2(170+34)=102$, and for ideal standard deviation $(\mathrm{SD})=1 / 6(170$ $34)=22.67$. Evaluation criteria according to the ideal formula are clearly presented in Table 3.

Table 3. Evaluation Criteria of Learning Process

\begin{tabular}{cc}
\hline Interval & Criteria \\
\hline $\mathrm{X}>136$ & Very good \\
$113.33<\mathrm{X} \leq 136$ & Good \\
$90.67<\mathrm{X} \leq 133.33$ & Pretty good \\
$68<\mathrm{X} \leq 90.67$ & Poor \\
$\mathrm{X} \leq 68$ & Not good \\
\hline
\end{tabular}

Implementation of the assessment is measured using an assessment document, using a data aggregation technique, namely document analysis. In these components, there were 15 items with a range of scores from 1 to 4 . From the calculations, it could be seen that the highest ideal score is 60 and the lowest ideal score is 15 . Thus, ideal mean $(M)=1 / 2(60+15)=37.5$ and for ideal standard deviation $(\mathrm{SD})=1 / 6(60+15)=$ 7.5. Evaluation criteria according to the ideal formula are presented in Table 4.

Table 4. Evaluation Criteria of Process Assessment

\begin{tabular}{cc}
\hline Interval & Criteria \\
\hline $\mathrm{X}>48.75$ & Very good \\
$41.25<\mathrm{X} \leq 48.75$ & Good \\
$33.75<\mathrm{X} \leq 41.25$ & Pretty good \\
$26.25<\mathrm{X} \leq 33.75$ & Poor \\
$\mathrm{X} \leq 26.25$ & Not good \\
\hline
\end{tabular}

The outcome aspect of this study was measured through the results of students' midterm examinations. The score which was obtained from the teacher was then compared with the graduate competency standard or Standar Kompetensi Lulusan (SKL) of each school. After being compared with the SKL, the results were then categorized as graduated and not graduated for each school.

The evaluation criteria were used to analyze and interpret the results of data processing obtained. In other words, the judgment or categorization of the average score in the field in each aspect referred to the ideal average criteria except for the outcome aspect. The average achievement score in the field was then converted to the percentage of achievement with the following formula.

Achievement Percentage $=\frac{\text { average achievement score }}{\text { maximum ideal average for each aspect }} \times 100 \%$

Table 5. Criteria of Learning Program Success

\begin{tabular}{clc}
\hline Stages & \multicolumn{1}{c}{ Aspects } & $\begin{array}{c}\text { Success } \\
\text { criteria }\end{array}$ \\
\hline Antecedent & Lesson Plan & $100 \%$ \\
Transaction & $\begin{array}{l}\text { Learning process } \\
\text { Assessing process }\end{array}$ & $100 \%$ \\
Outcomes & Students' score & $80 \%$ \\
\hline
\end{tabular}

The result of the percentage was then compared to the standard based on Table 5 . Success criteria for learning programs are obtained from the content standards, process standards, and also assessment standards. For content standards and process standards refer to the suitability of standards set by the government, then the success criteria must be $100 \%$. In contrast to the content standards and process standards, the aspect of results only stands at $80 \%$ due to differences in graduation standards per school.

\section{Findings and Discussion}

Implementation of learning in the classroom should become a concern for teachers, especially mathematics teachers because the good implementation of learning gives impact to student learning outcomes. In this study, there are three stages, namely the antecedent, transaction, and outcome stages. Of the three stages, the antecedent and transaction stages use five categories, which are very good, good, good enough, not good, and not good, while for the outcome phase, only the graduated and non-graduated categories are used. The results of this study indicate that the assessment of lesson plan documents is included in the good category, while the assessment documents are included in the category of 
quite good. It is because of the percentage obtained from the two variables, which is, more than $50 \%$. The implementation of learning got a pretty good category with a percentage of $67.07 \%$. In addition, for the outcomes phase, the midterm grades for 10 schools do not meet the minimum completion criteria.

Assessment for the learning plan document made by teachers was conducted using instruments that refer to the Regulation of Minister of National Education No. 22 of 2006 concerning the content standards for primary and secondary education units. Learning planning is said to be good if the teacher makes a learning/lesson plan in accordance with the established standards. The results of the analysis are then compared with the success criteria set at $100 \%$.

\section{Antecedent}

A lesson plan is a very important document for both the teacher and other teaching staffs, so whenever a teacher implements learning, he/she already understands what will be taught in class. In addition, the learning planning document will also help the teacher to make them go back to the track whenever the learning process does not run as planned. In this study, the learning plan or lesson plan documents that have been prepared by teachers are then assessed using document review. Overall, the teacher makes the design of the learning plan very good. It is evidenced by $93.45 \%$ of learning plans made by teachers which are included in the excellent category. In other words, in planning learning, the teacher has carried out good planning activities. Based on interviews with teachers, they receive training from the government regarding the learning process, making it easier to create lesson plans for learning implementation even though some teachers are still difficult to apply the knowledge gained through the training. It can be concluded that the evaluation of the learning plan is included in the good category, but consideration remains. The consideration referred here is that the teacher must pay attention to the suitability of the formulation of indicators with the competence standard and also basic competence, as well as the selection of learning models that are in accordance with the characteristics of students. The results show that the two items are included in the quite good category. Therefore, teachers have not considered the competence standard and basic competence in the formulation of indicators and the selection of learning models. Whereas, according to Salmayzuri et al. (2015), learning planning is conducted in accordance with the established standards. In addition, research conducted by Morris and Hiebert (2017) reveals that planning is very important in learning so that it will have a positive influence on the students' achievement.

Transaction Aspect of Learning Implementation

Evaluation at the transaction stage is an evaluation of the learning process in the classroom and assessment documents. The researcher and rater conduct an assessment of the learning process conducted by the teacher in the classroom. Observation of the learning process in the classroom is done by using an observation sheet instrument that refers to the Regulation the Minister of National Education of Republic of Indonesia No. 41 of 2007 concerning the standard processes for primary and secondary education units. In the learning process, there are three stages, namely the preliminary, core, and closing stages. Observations of the three activities refer to the established process standards. The learning process is said to be good if the teacher carries out the learning process in accordance with the stages in the standard process. The results of the analysis are then compared with the success criteria set at $100 \%$.

In contrast to the learning planning described earlier, evaluation of learning observations obtains a quite good category. Based on observations, some teachers do not do what is written in the document. There are three sub-indicators in this stage, 
namely, preliminary, core, and closing activities. Thus, it can be concluded that in the implementation of learning, there are things that are not in accordance with the planning of learning.

When confirmed to the teacher by using an interview, it was found that there are some obstacles felt by the teacher when teaching, namely, lack of learning resources, and feeling burdened when teaching mathematics because the teacher's educational background is not from mathematics education. Both of these obstacles result in the teacher feeling difficulties in implementing learning in accordance with the standard process. When compared with the standard, there is a gap of $32.93 \%$. Improvements must be made to all aspects, namely preliminary, core, and closing activities because, in all three activities, the teacher does not carry out the stages according to the standard, for example, the teacher does not carry out preliminary activities such as providing motivation to students before the lesson begins.

The results of this study are in line with research conducted by Lukum (2015) where the learning process is not in accordance with the established process standards. In addition, Waluyati (2012) also states that the learning process carried out in junior high school/Islamic-based junior high school in the city of Bima was included in the quite good category. Thus, it can be concluded that the learning process has not been carried out in accordance with existing process standards. It is because the expected standard of learning is $100 \%$. Research conducted by Bolkan, Goodboy, and Myers (2017) is in line with the results of this study which states that explanations from teachers affect students' mathematics learning outcomes. Therefore, the decision taken is the consideration to improve the process of implementing learning. The consideration that can be given is that the teacher is more able to apply what has been written in the learning plan. In addition, the teacher must master the material first before delivering information to students.

\section{Transaction Aspect of Assessment}

The assessment of assessment documents made by the teacher was done using the document review sheet instrument made based on the Regulation of Minister of National Education No. 22 of 2006 concerning the assessment standards for primary and secondary education. In evaluating students' learning outcomes, teachers are required to make several instruments or assessment documents which have been determined by the government. Assessment documents are said to be good if the teacher has made an assessment document in line with applicable assessment standards. The results of the analysis are then compared with the success criteria set at $100 \%$.

Assessments assessed in this study are assessment documents that have been written by the teacher. The assessment document was then assessed using a review sheet of the assessment document to see its conformity with the assessment standard. From the results of the study, it is found that the assessment documents are included in the category of quite good with a percentage of $71.34 \%$. In the assessment document review sheet, there are five sub-indicators, divided into sub-indicators of the completeness of the set of assessment documents, set of techniques, preparation of assessment strategies, processing assessment, and conducting the assessment. Thus, it indicates that the assessment documents are in a quite good category with consideration. Activities that need to be improved in carrying out the assessment are the instrument grids, the use of non-test assessment instruments, the multiple-choice assessment guidelines, the use of multiple-choice tests, the assessment using observation sheets, and the assessment is carried out in the form of daily tests. Teachers are expected to complete the assessment documents in accordance with the established standards. Interviews were conducted with the teacher during the observation process. The interview results found that the teacher applies knowledge when training to conduct assessments in the classroom. When observing, the teacher as- 
sesses students as questions and answers as stated in the learning implementation plan, however, the completeness of the assessment documents is not given enough attention. It is similar to what was expressed by Noviana and Kartowagiran (2015) whose research results reveal that the teacher has carried out the assessment very well because they not only did the assessment during the test but also during the learning process. However, the lack of the assessment document causes the assessment is included in a quite good category. The use of grading rubrics will help the teacher to grade consistently. It is in accordance with Jönsson and Panadero (2017) who report that there are two advantages if the teacher makes an assessment rubric, namely, helping the teacher in terms of the consistency of assessment, and it can improve the instruction done by the teacher after giving feedback in learning. To improve the implementation of assessments conducted by teachers, the government should disseminate information to teachers to complete the assessment documents such as grading instrument assessment, rubric assessment essay questions, and conduct training to analyze the results of the assessment (Setiadi, 2016).

\section{Outcomes}

Evaluation of outcome is an assessment of the results of students' midterm test grades. The resulting score is then matched with the graduate competence standard or Standar Kompetensi Lulusan (SKL) value, so that the pass and not pass categories will appear. Based on the results of the study, it is recognized that $43 \%$ of students are declared to have passed or exceeded the SKL score, while $57 \%$ are declared not to pass. We can ignore the majority of students not fulfilling the SKL grades because the implementation of learning is still not very good for many students who have not exceeded the SKL score. The results of the study are in line with the research conducted by Lukum (2015) which agrees to the learning conducted by the teacher that is not in accordance with the existing standards so that students are unable to meet the SKL. It is because the specified standard is $100 \%$, whereas, at the specified time, students who meet the SKL score are less than $50 \%$. Therefore, teachers need to consider what is given by researchers in order to improve the learning process. Ngware, Ciera, Musyoka, and Oketch (2015) also state the quality of the teacher positively contributes to improving student learning achievement. Moreover, Ottmar, Decker, Cameron, Curby, and RimmKaufman (2014) reveal different research results that there is no relationship between the quality of learning with an increase in student achievement. The same thing was agreed by Fung et al. (2017) that the pedagogical ability of teachers supports student achievement. Thus, it can determine the number of students who cannot meet the SKL to determine the quality of learning that is not in accordance with predetermined process standards. Student learning outcomes can be improved by the methods used by teachers. Therefore, the teacher must recognize several learning strategies so that students have the motivation to learn so as to improve student achievement. The learning strategy used in a research conducted by Wahyuni and Jailani (2017) is realistic mathematics learning. The result of the study is that realistic learning can increase motivation and learning achievement of elementary school students.

After a description of the stages in the implementation of the learning program, then a comparison is made between the ideal conditions in accordance with the established standards and actual situation when on the field, then the gap between stages is seen vertically. The results show that the teacher could make plans for implementing learning very well in accordance with the school-based curriculum. Based on the results of observations made during the learning process, there is a mismatch between planning and learning implementation. The assessment documents made by the teacher are included in the quite good 
category. The teacher has not made an assessment document in accordance with the specified standards. It makes student learning outcomes less favorable because the tendency in every school is not yet to meet the minimum completion criteria.

Overall, the teacher has done a very good planning because they have received training from the government which makes them to create lesson plans for the learning implementation, even though some of them are still difficult to apply the knowledge gained through training. Ideally, good planning will facilitate the teacher in implementing the learning process. However, it did not happen. The implementation of learning in this study is only included in the category of quite good. This discrepancy occurs because teachers have difficulty in implementing planning that has been made such as providing motivation in preliminary activities not done by the teacher. The assessment documents made by the teacher still need a lot of improvement because the results of the analysis of the assessment documents are included in the quite good category. The discrepancy has an impact on student learning outcomes. The results of the analysis on the aspects of student learning outcomes indicate that the tendency in each school is not yet fulfilling the minimum completion criteria score. It might be the result of a mismatch between the learning plan, the assessment documents, and the learning implementation. Besides, the high minimum completion criteria score in each school is also one of the consequences of many students who do not meet the minimum completion criteria score.

\section{Conclusion}

Based on the results of the study, it is concluded that the evaluation of the antecedent component, namely the planning of learning programs, is in the good category of $93.45 \%$. Evaluation of the transaction component, namely the implementation of the learning process aspects of the process is included in the category of quite good by $67.07 \%$. Meanwhile, evaluation of the trans- action component, namely aspects of the assessment of learning, is included in the quite well category by $71.34 \%$. Finally, the results of the evaluation on the outcome component are more than $50 \%$ of students included in the category of not passing.

\section{References}

Andriani, S. (2015). Evaluasi CSE-UCLA pada studi proses pembelajaran matematika. Al-Jabar: Jurnal Pendidikan Matematika, 6(2), 167-175. https:// doi.org/10.24042/ajpm.v6i2.46

Azwar, S. (2016). Reliabilitas \& validitas (IV). Yogyakarta: Pustaka Pelajar.

Azwar, S. (2017). Penyusunan skala psikologi. Yogyakarta: Pustaka Pelajar.

Bahri, H. A., \& Alimuddin, A. (2016). The profile of teacher's understanding on student's mathematics ability based on teacher's teaching experience at SMPN 1 Gantarangkeke. Jurnal Daya Matematis, 4(2), 119-128. Retrieved from https://ojs.unm.ac.id/JDM/arti cle/view/2892/pdf_31

Bolkan, S., Goodboy, A. K., \& Myers, S. A. (2017). Conditional processes of effective instructor communication and increases in students' cognitive learning. Communication Education, 66(2), 129-147. https://doi.org/ 10.1080/03634523.2016.1241889

Burton, D. T., \& Kappenberg, J. W. (2013). Mathematics, the common core, and RTI: An integrated approach to teaching in today's classrooms. Newbury Park, CA: Corwin Press.

Dole, F. E., \& Wibowo, U. B. (2013). Kemampuan guru mengimplementasikan KTSP pada SD di kecamatan Detukeli Kabupaten Ende. Jurnal Prima Edukasia, 1(2), 147-161. https: //doi.org/10.21831/jpe.v1i2.2632

Fernandes, H. J. X. (1984). Evaluation of educational programs. Jakarta: National Education Planning, Evaluation and Curriculum Development. 
Fitzpatrick, J. L., Sanders, J. R., \& Worthen, B. R. (2011). Program evaluation: Alternative approaches and practical guidelines (4th ed.). Boston, MA: Pearson Education.

Fung, D., Kutnick, P., Mok, I., Leung, F., Lee, B. P.-Y., Mai, Y. Y., \& Tyler, M. T. (2017). Relationships between teachers' background, their subject knowledge and pedagogic efficacy, and pupil achievement in primary school mathematics in Hong Kong: An indicative study. International Journal of Educational Research, 81, 119_ 130. https://doi.org/10.1016/j.ijer. 2016.11.003

Gwet, K. L. (2012). Handbook of inter-rater reliability: The definitive guide to measuring the extent of agreement among multiple raters (3rd ed.). Gaithersburg, MD: Advanced Analytics.

Jönsson, A., \& Panadero, E. (2017). The use and design of rubrics to support assessment for learning. In D. Carless, S. M. Bridges, C. K. Y. Chan, \& R. Glofcheski (Eds.), Scaling up assessment for learning in higher education (pp. 99-111). https://doi.org/ 10.1007/978-981-10-3045-1_7

Kasih, P. A., \& Purnomo, Y. W. (2016). Peningkatan hasil belajar matematika siswa sekolah dasar melalui pembelajaran berbasis penilaian. Journal of Research and Advances in Mathematics Education, 1(1), 69-78. https://doi. org/10.23917/jramathedu.v1i1.1776

Kaufman, R. A., \& Thomas, S. (1980). Evaluation without fear. Newberry, FL: New Viewpoints.

Lukum, A. (2015). Evaluasi program pembelajaran IPA SMP menggunakan model Countenance Stake. Jurnal Penelitian Dan Evaluasi Pendidikan, 19(1), 25-37. https://doi.org/ 10.21831/pep.v19i1.4552

Mardapi, D. (2009). Evaluasi penerapan ujian akhir sekolah dasar berbasis standar nasional. Jurnal Penelitian Dan Evaluasi Pendidikan, 13(2), 227-245. https://doi.org/10.21831/pep.v13i2. 1411

Mardapi, D. (2012). Pengukuran, penilaian, dan evaluasi pendidikan. Yogyakarta: Nuha Medika.

Maryani, I., \& Fatmawati, L. (2015). Pendekatan scientific dalam pembelajaran di sekolah dasar: Teori dan praktik. Yogyakarta: Deepublish.

Morris, A. K., \& Hiebert, J. (2017). Effects of teacher preparation courses: Do graduates use what they learned to plan mathematics lessons? American Educational Research Journal, 54(3), 524-567. https://doi.org/10.3102/ 0002831217695217

Ngware, M. W., Ciera, J., Musyoka, P. K., \& Oketch, M. (2015). Quality of teaching mathematics and learning achievement gains: Evidence from primary schools in Kenya. Educational Studies in Mathematics, 89, 111-131. https://doi.org/10.1007/s10649-0159594-2

Niwaz, A., Shah, S. Z. H., \& Rajper, A. K. (2016). Lesson planning in teaching of mathematics: Teachers' perceptions and current practices. The Sindh University Journal of Education, 45(1), 45-66.

Noviana, N., \& Kartowagiran, B. (2015). Evaluasi implementasi penilaian otentik pembelajaran Bahasa Indonesia pada Kurikulum 2013 di SMA. Jurnal Evaluasi Pendidikan, 3(2), 157-166. Retrieved from http:// journal.student.uny.ac.id/ojs/index.p $\mathrm{hp} / \mathrm{jep} /$ article/download/1271/1146

Ottmar, E. R., Decker, L. E., Cameron, C. E., Curby, T. W., \& Rimm-Kaufman, S. E. (2014). Classroom instructional quality, exposure to mathematics instruction and mathematics achievement in fifth grade. Learning Environments Research, 17, 243-262. 
https://doi.org/10.1007/s10984-0139146-6

Ramirez, G., Chang, H., Maloney, E. A., Levine, S. C., \& Beilock, S. L. (2016). On the relationship between math anxiety and math achievement in early elementary school: The role of problem solving strategies. Journal of Experimental Child Psychology, 141, 83100. https://doi.org/10.1016/j.jecp. 2015.07.014

Regulation of Minister of National Education No. 22 of 2006 on Content Standard. , (2006).

Regulation of the Minister of National Education No. 19 of 2005, on National Standard of Education., (2005).

Regulation of the Minister of National Education No. 20 of 2007 on the educational assessment standard., (2007).

Regulation the Minister of National Education of Republic of Indonesia No. 41 of 2007 on Process Standard for Primary and Secondary Educational Units. , (2007).

Rosnani, R., Sugiyono, S., \& Tampubolon, B. (2015). Peningkatan hasil belajar pada pembelajaran matematika menggunakan alat peraga realita di kelas 1 sekolah dasar. Jurnal Pendidikan Dan Pembelajaran Khatulistiwa, 4(1), 19. Retrieved from http://jurnal.untan. ac.id/index.php/jpdpb/article/view/ $8529 / \mathrm{pdf}$

Rossi, P. H., \& Freeman, H. E. (1985). Evaluation: A systematic approach. Beverly Hills, CA: Sage.

Salmayzuri, S., Ruslan, R., \& Pristiwaluyo, T. (2015). Evaluasi program pembelajaran matematika di SMA Negeri Watansoppeng. Riset Assesmen: Jurnal Penelitian Dan Evaluasi Pendidikan, 1(1), 1-8. Retrieved from https://ojs.unm.ac.id/assesment/arti cle/view/1778

Setiadi, H. (2016). Pelaksanaan penilaian pada kurikulum 2013. Jurnal Penelitian
Dan Evaluasi Pendidikan, 20(2), 166178. https://doi.org/10.21831/pep. v20i2.7173

Setiawan, I. (2016). Peningkatan hasil belajar matematika pada materi pecahan siswa kelas III SD Negeri Bendungan III dengan alat peraga. Basic Education: Jurnal Elektronik Mahasiswa Prodi PGSD, 5(3), 214-226. Retrieved from http://journal. student.uny.ac.id/ojs/index.php/pgs $\mathrm{d} /$ article/view/873

Singh, Y. K. (2008). Teaching practice: Lesson planning. New Delhi: APH Publishing.

Stake, R. E. (1996). For all program evaluations there's a criterion problem. Evaluation - The International Journal of Theory, Research and Practice, 2(1), 99-103.

van de Walle, J. A. (2008). Matematika sekolah dasar dan menengab: Pengembangan pengajaran jilid 1. Jakarta: Erlangga.

Wahyuni, N. D., \& Jailani, J. (2017). Pengaruh pendekatan matematika realistik terhadap motivasi dan prestasi belajar siswa SD. Jurnal Prima Edukasia, 5(2), 151-159. https://doi. org/10.21831/jpe.v5i2.7785

Waluyati, I. (2012). Evaluasi program pembelajaran ilmu pengetahuan sosial SMP/MTs di Kota Bima. Jurnal Penelitian Dan Evaluasi Pendidikan, 16(1), 260-280. https://doi.org/ 10.21831/pep.v16i1.1117

Wibowo, R., \& Wutsqa, D. U. (2014). Evaluasi pelaksanaan Kurikulum Tingkat Satuan Pendidikan (KTSP) mata pelajaran matematika SMP di Kota Yogyakarta. Jurnal Riset Pendidikan Matematika, 1(1), 58-68. https://doi.org/10.21831/jrpm.v1i1. 2664 